\title{
Study on Russian ethnology after the collapse of the Soviet Union
}

\author{
Huang Yanzhen
}

Shaanxi Xueqian Normal University, Xi`an, Shaanxi, China, 710000

Keywords: Russia, ethnology, history of development

\begin{abstract}
Any science has to undergo a complex and changing development process. As the composition of the social science of ethnology, due to the change of social demand in different historical period, the research object, research scope and research methods are also changing. This changing process also makes the history of the subject is constantly enriched. This paper put the Soviet Russian ethnology as research object, and it analyzed the hot issues of Russian ethnology by combing the Russian ethnology history, and it displayed the general picture of the development of Ethnology in Russia. Firstly, this paper reviewed the development history of Russian Ethnology; this paper introduced the Russian ethnology "crisis" and subject status, and it analyzed the Shirokogoroff's academic thoughts and the national theory and social influence of L.N.Gumilyov. Finally, this paper analyzed the Russian Ethnology in the new millennium. Through the study, we find that subject is still faced with many problems, one of the most important is the problem of discipline team construction and personnel training, and financial difficulty seems to be a common problem in all disciplines. Russia has opened up more channels of Ethnology funds at home and abroad, and completed many major scientific research projects, and the shortage of funds is still largely hindered the development of science, especially the development of local ethnology.
\end{abstract}

\section{INTRODUCTION}

After the disintegration of the Soviet Union, Russia became the history of the Soviet Union, and inherited the Soviet era in science, culture, education and the creation of rich material and spiritual heritage [1]. This lays a solid foundation for Russia to develop Ethnology in the new social environment. Ethnology knowledge and results can be applied to social practice to a great extent, and it has more and more influence on society, and its social status was greatly improved compared with the Soviet period.

Study on Russian ethnology is a wide and rich topic. This paper focuses on the Russian ethnology important discipline problems and phenomenon in the process of research subject. In addition, this paper uses the method of objective description and brief analysis was introduced to Russian ethnology organization system [2]. The author hopes that this thesis can show the overview of the development of Ethnology for domestic counterparts in Russia, and it can enrich our "Russian ethnological research" to do some useful work.

\section{RESEARCH CONTENTS}

\subsection{The history of the development of Russian Ethnology}

According to the "Ethnology basis" written by the Russian National scientist Pi May Andrianof, we put the historical process of the development of Ethnology in Russia is divided into four stages [3]. The characteristics of these four stages are seen in Table 1:

Table.1 the Russian ethnology development stage and characteristics

\begin{tabular}{|c|c|}
\hline $\begin{array}{l}\text { Stage of } \\
\text { development }\end{array}$ & Characteristic \\
\hline $\begin{array}{lr}\text { Early } & 18 \text { th } \\
\text { century } & - \\
\text { Early } & 19 \text { th } \\
\text { century } & \\
\end{array}$ & $\begin{array}{l}\text { The work which had the nature of Ethnology began to sprout. } \\
\text { Ethnology as an independent discipline had not yet formed. }\end{array}$ \\
\hline 18th & Organizations of Ethnology began to set up; Royal Geographical \\
\hline
\end{tabular}




\begin{tabular}{|l|l|}
\hline $\begin{array}{l}\text { century - } \\
\text { Early 20th } \\
\text { century }\end{array}$ & Society of Russia established \\
\hline 1920 s - 1940s & $\begin{array}{l}\text { The pluralist view deep into every field of ethnology; The scope of } \\
\text { the study subjects significantly reduced }\end{array}$ \\
\hline 1950 s - 1980s & $\begin{array}{l}\text { Ethnology theory had been in active development; a group of famous } \\
\text { national experts had made outstanding contributions to the world } \\
\text { development of ethnology, }\end{array}$ \\
\hline
\end{tabular}

(1) Budding period: At the beginning of eighteenth Century, the work which had the nature of Ethnology began to sprout. By the beginning of nineteenth Century, Russia had accumulated a large amount of information about its ethnic and national culture and life. However, ethnology as an independent discipline had not yet formed. [4]

(2) Formation period: The first half of nineteenth Century, Russia's domestic political environment promoted the formation of ethnology. In 1840s, some organizations of Ethnology began to set up. In 1845, the Russian Royal Geographical Society established in St. Petersburg [5]. This is a symbol of Russia officially formed ethnology. An empirical study on the work of Russia before twentieth Century belongs to ethnology to a great extent. The results of this period reach the level of the other countries of Europe at the same time in theory and methodology. Russian ethnology work is an empirical study of ethnology in the very great degree before 20th Century.

(3) Development period: In the 1920s, Ethnology got great development in theory, organization, personnel training and so on during the period, the pluralist view deep into every field of ethnology, first reflected in the theory method, and evolution was still dominant. In 1930s, the ethnology research institutions were greatly reduced, and the scope of the study subjects significantly reduced, as well as the teaching institutions to stop work [6]. Until the Great Patriotic War before, the subject was able to recover gradually. During the Great Patriotic War, many institutions of Ethnology evacuated to the city of Ashkhabad and some eastern, and the number of researchers was also greatly reduced.

(4) Theoretical development period: After the Great Patriotic War, ethnology theory had been in active development. In 1950s to 1960s, a group of famous national experts had made outstanding contributions to the world development of ethnology, and the most representative figure is Tokarev. In 1970s-1980s, some influential groups formed in the Soviet ethnology various republics and autonomous republic,

\subsection{The Russian ethnology "crisis" and subject status}

After the disintegration of the Soviet Union, Russia became the historical inheritance of the Soviet Union. Russian Ethnology is also undergoing profound changes in the dramatic changes in society. At the beginning of 1990s, the whole Russia society was plunged into a deep revolution. Change had created positive conditions for the development of society, and it also brought negative effects, and the country's economic life is in a state of serious crisis. Ethnology had come to the crossroads of development [7]. In 1992, Valery Tishkov wrote the Soviet ethnology crisis. In the article, he said:" The "crisis" I put forward is not just the social background of our subject, but also the subject itself, including the Institute of Anthropology and ethnology, Russian Academy of Sciences.”

He believed that the whole social and scientific fields were experiencing a crisis, and the ethnology crisis is just one part of the crisis. At present, the ethnology discipline status, social status and material basis and the social demand for ethnology is extremely incompatible. The discipline status, social status, material basis of ethnology did not correspond with the social needs of Ethnology. It was not conducive to the free creation of the scholars that the discipline system and model was rigid. Most importantly, there was no market for the results of the work of the nation's scholars, which led to the scholars, have lost the passion for creation. He also saw that the ethnology "organism" suffered from various "diseases". Among them, the most serious was the lack of introspection and self analysis.

After the publication of the article written by Valery Tishkov, it stirred up the great discussion 
about the essence of the "crisis" of subject, fur rent situation of subject and future development trend of the discipline. Many scholars used the "ethnology review" platform to actively participate in the discussion, and explained their views. The views and reasons of the scholars are shown in the following table:

\begin{tabular}{|l|l|} 
Table.2 Views of scholars of Ethnology "crisis" \\
\begin{tabular}{|l|l|}
\hline Scholar & Viewpoint \\
\hline Valery Tishkov & $\begin{array}{l}\text { The whole social and scientific fields were experiencing a crisis, } \\
\text { and the ethnology crisis is just one part of the crisis. }\end{array}$ \\
\hline $\begin{array}{l}\text { A. A. Nikisch } \\
\text { Kopf }\end{array}$ & $\begin{array}{l}\text { Ethnology was in a completely different society, and it needed } \\
\text { to adjust itself }\end{array}$ \\
\hline $\begin{array}{l}\text { C. H. brooke } \\
\text { Domestic ethnology experience was not a "crisis", but the } \\
\text { reform }\end{array}$ \\
\hline $\begin{array}{l}\text { JI. M. Pedro Pi } \\
\text { Geva }\end{array}$ & $\begin{array}{l}\text { Ethnology was not experienced in the "crisis" , but was } \\
\text { entering the development of the track }\end{array}$ \\
\hline
\end{tabular}
\end{tabular}

\subsection{The return and research status of Shirokogoroff's academic thoughts}

Shirokogoroff is one of the most talented scholars, and he put the mathematics, medicine, biology, and other disciplines of knowledge into the ethnological research on their own. He studied the theory of the West, and in this view, the theory of evolution and culture circle contains reasonable judgment but there are also shortcomings. Shirokogoroff believes that ethnology is a human science research, covering all phenomena exist in human reality, and there is no artificial boundary between the physical condition of the nation and the whole of its cultural elements.

Shirokogoroff attached great importance to the research of the national theory during his sojourn in Chinese. He used the "эTHOC" said the "nationality" of the research object. Although the term appeared in the middle of the 19th Century Russian language, however, Shirokogoroff was the first to use "эТНОC" in the category of ethnology. He coined the term "national balance" (эТНИЧеckoe paBHOBeche). The ethnic balance is determined by the number of ethnic groups, the region inhabited by ethnic groups, and the degree of adaptation to the environment.

About Shirokogoroff's national theory, Fei Xiaotong made such a summary: The most exciting analysis of his Ethnos theory is that an Ethnos (эTHOC) unit can be represented by an arithmetic formula, and it also shows the respective energy in the contact with the same kind of units. So the last word of his theory is: Ethnos (эTHOC) itself is a process of changing, and the Anthropology is the study of Ethnos (эTHOC) change process. In our words, it is the nation's rise and decline, which is a dynamic research. Through the efforts of some scholars, some books and articles of Shirokogoroff published in foreign history was translated into Russian. His academic thought has received more and more scholars' attention. Even some scholars believed that he was the real founder of ethnic theory.

\subsection{The national theory and social influence of L.N.Gumilyov}

The national and ethnic origin theory of Gumilyov can be simply summarized as follows:

(1) Some unknown energy in the universe is projected to a specific region of the earth's surface, and it can cause the outbreak of passion (ВэрбІВ пасИОНарНОСТИ) of the people in this region, which made the people of this area have a special "mental state of mind"

(2) Nation is a population, and it is a biological unit, which is also a natural phenomenon. It is "absurd" to study the phenomenon of nation through the law of social development. In the life of the nation, the "passion" plays a special role. "Passion" is an extraordinary and capable of absorbing energy from the surrounding environment. He divided the nation into "rich and passionate people" and "the weaker people" "

In the 1960s and early 1970s, the article published by Gumikei J in the National Geographic magazine has aroused the concern of the society for its theory. The article published in China Geographic magazine had aroused the concern of the society for its theory. At the end of 1980s, the social influence of the theory gradually strengthened, and he gradually became "the master of the thought" from a "marginal man". After 1990s, his influence continued unabated. In 2002, the Republic of Altai named a nameless mountain as Gumilyov. The ethnic origin and source theory 
can't be ignored in social and discipline phenomenon in the field of social and academic influence.

\section{RUSSIAN ETHNOLOGY IN NEW MILLENNIUM}

\subsection{Russia's new research direction of Ethnology}

After 1990s, on the basis of traditional research, Russian ethnology gradually on the rise new research direction in order to meet the needs of the society, such as religious studies, research on immigration, gender issues, urban anthropology, law anthropology, medical anthropology, animal behavior science, anthropology, political academic anthropology, visual anthropology and research on conflict and ethnic relations. Russian national research is one of the important research directions in the discipline, including in Russian history, culture, land development, orthodox history and function, the status of overseas Russians, Russian immigrant history content.

\subsection{Problems and difficulties in the development of Russian Ethnology}

Problems and difficulties in the development of Ethnology in Russia can be summarized as follows:

(1) Problems in scientific research creation: With the advent of a large number of scientific research products, the research quality showed a downward trend. Many articles lack the connotation, and the quality is low; the subject repetition problem increases, resulting in the waste of intelligence and resources; some scholars' work enthusiasm is not high.

(2) Problems of talents training and discipline team: Some scholars regard the overall state of the Russian ethnology team described as "old and clumsy". The reason is that in recent years, the number of young people in ethnology team is very few. Due to economic and other reasons, many middle-aged scholars choose to go to a foreign university to teach, or choose other industries. Brain drain phenomenon is very serious. There are many objective reasons which can cause the research team "aging", one of the main reasons is that the social status of ethnology is not high and their wages are low...

(3) Research funding problems: In the process of the development of Russian ethnology, many research projects require funding support. Therefore, the shortage of scientific research funds has been a reality, cannot avoid the difficulties and problems. In addition to rely on Institute of finance budget capital, ethnology and Anthropology Research Institute annual scientific research project funds from various funds will support. At present, the fund application system is not very perfect and perfect. Compared with the central research institutions, local ethnology research get the amount of funds is less, which is a serious impediment to the development of local research.

(4) The issue of internationalization of Russian Ethnology: From 1990s, Russian ethnology has been recognized that Russian Ethnology is a part of the ethnology and anthropology, if it wants to get more development, it must overcome distance and gap with the international academic circles. In exchange and cooperation with the international academic community, the biggest obstacle is the language and financial problems. Few scholars read foreign professional journals, and know little about the frontier information of foreign subjects, and the two academic conferences held in the United States has not yet been the figure of Russian scholars. Only a small part of the Russian domestic scholars on the development of the international community is more concerned about the situation. They become the western academic thought of "translator" and "the narrator". Due to the rapid renewal of western academic ideas, many of the views in the western academic circles have "delay" in Russian academic circles.

(5) The problem of "unification" and "identity" of academic community: In 20 years of development history, Russian ethnology whether it has formed a stable, unified academic groups, on this issue; the scholar's views are not uniform. In 20 years of development history, whether the Russian ethnology has formed stable, unified academic groups, on this issue, the scholar's views are not uniform. Some scholars believe that, since the ethnology independent discipline already exists, and there are a large number of Ethnology workers. Then this group is the objective existence. However, some scholars believe that, no matter from the organization, or the spiritual level, there is no sense of the existence of this group, but there are a number of small research teams and academic factions. 
Tishkov said: "the existence of Ethnology's academic groups in question is meaningless to me personally. I will put much of my energy in support, consolidation and development of the cause of this group and the existence of this group is no dispute, otherwise, we are who?"

Many scholars put forward pertinent suggestions to this problem. For example, some scholars hope that as Russian ethnology most important academic journals, the ethnology review should play a greater role in the process of establishing academic community. In addition, scholars very much hope that establish a unified research site, will be the new thesis, articles, reviews, and fieldwork log data published in the network, let the national scholars share resources. Scholars want to establish unified research site, and the latest dissertations, articles, reviews, and fieldwork log data are published in the network, so that it can let the national scholars share resources. Believe that these suggestions will be on the formation of a unified, stable and healthy ethnology study groups play a positive role in promoting.

\section{RESEARCH RESULTS}

Through the above research and analysis, we can find that although in the development process, the Russian ethnology gradually gets rid of "crisis", and it has made no small achievement, but subject is still faced with many problems, one of the most important is the problem of discipline team construction and personnel training. To solve this problem requires ethnology co-operation, make deep reform in course system and Ethnology in the education system, and it needs to improve the personnel training mode and training mechanism. Secondly, financial difficulty seems to be a common problem in all disciplines. Russia has opened up more channels of Ethnology funds at home and abroad, and completed many major scientific research projects. However, the shortage of funds is still largely hindered the development of science, especially the development of local ethnology. Throughout 20 years development of the Russian ethnology, Ethnology met many obstacles and challenges, and it has also made remarkable achievements in science, and "transformation" and "innovation" is always the main theme of the subject development.

\section{ACKNOWLEDGMENT}

This work was supported in part by the social science and humanity on Young Fund of the ministry of Education, 14YJC850006.

\section{REFERENCES}

[1] Zhongli M A, Huacong Y E, Chen H, et al. Evolution of Russian Sport Policy after the Collapse of the Soviet Union[J]. Journal of Shanghai University of Sport, 2014(2):37-42.

[2] Napieralska A. Russian-Moldovan Relations after the Collapse of the Soviet Union[J]. Dissertations \& Theses - Gradworks, 2012.

[3] Bragina E V, Ives A R, Pidgeon A M, et al. Rapid declines of large mammal populations after the collapse of the Soviet Union.[J]. Conservation Biology, 2015, 29(in press):844 - 853.

[4] Shi N Q. Meng Wentong's Ethnohistory and Ethnology Research[J]. Journal of Yibin University, 2012.pp.32-43

[5] Wiener B E. The cognitive structure of modern Russian ethnology according to data presented in journal citations: a preliminary analysis[J]. Vestnik Sankt-Peterburgskogo Universiteta, Seriia 2: Istoriia, 2013.pp.12-16

[6] Gorbunova J S, Devyatova T A, Grigorjevskaya A Y. Fire influence on the soil and plant cover of forests in the Central Chernozem Region of Russia[J]. Arid Ecosystems, 2014, 4(4):285-293.

[7] Dusik J M, Leopold M, Heckmann T, et al. Influence of glacier advance on the development of the multipart Riffeltal rock glacier, Central Austrian Alps[J]. Earth Surface Processes \& Landforms, 
2014, 40(7):965-980. 